\title{
IMPLEMENTASI KEBIJAKAN PEMBANGUNAN SUKU BADUY KABUPATEN LEBAK PROVINSI BANTEN
}

\author{
Sumawijaya $^{1}$, I Nyoman Sumaryadi ${ }^{2}$, Erliana Hasan ${ }^{3}$, Sampara Lukman $^{4}$ \\ ${ }_{1,2,3,4}$ Institut Pemerintahan Dalam Negeri (IPDN) \\ Email: sumawijaya1002@gmail.com
}

\begin{abstract}
Abstrak
Penelitian ini untuk mengkaji implementasi kebijakan pembangunan Suku Baduy, factorfaktor pendukung dan penghambat didalam pembangunan fisik dan nonfisik dan memberikan konsep-konsep baru dalam pembangunan masyarakat tradisonal primitive. Penelitian ini menggunakan metode kualitatif. Berdasarkan hasil penelitian menunjukan bahwa implementasi kebijakan tersebut mempengaruhi kondisi masyarakat Baduy yang selama ini terisolir dan tertinggal karena keterbatasan pembangunan fisik maupun non fisik mulai terbuka dengan masyarakat luar, namun perubahan dapat terjadi tanpa melanggar Pikukuh yang ditetapkan oleh Pu'un (Kepala Adat). Implementasi Kebijakan suku baduy mencakup isi kebijakan dan lingkungan kebijakan yang di dalamnya mencakup aspek kepentingan yang dipengaruhi, tipe manfaat, derajat perubahan dan pelaksana program.Pendekatan bottom-up merupakan yang paling tepat untuk digunakan dalam upaya penanggulangan pembangunan masyarakat Baduy, dimana masyarakat diposisikan sebagai pelaku (subyek) pembangunan yang diharapkan mempunyai pengaruh positif terhadap proses pemberdayaan masyarakat itu sendiri dalam upaya untuk membangun kemandirian. Sinkronisasi berbagai unsur berperan penting dalam implementasi kebijakan pembangunan suku Baduy. Dengan adanya sinkronisasi dalam proses implementasi, maka kebijakan pembangunan suku Baduy akan lebih terimplementasikan dengan baik.
\end{abstract}

Kata Kunci: Implementasi Kebijakan, Pembangunan Suku Baduy.

\begin{abstract}
This research is to examine the implementation of the Baduy Tribe Development Policy, supporting and inhibiting factors in physical and non-physical development and to provide new concepts in the development of traditional primitive societies. This study uses a qualitative method. Based on the results of the research, it shows that the implementation of this policy affects the condition of the Baduy community who have been isolated and left behind because of the limitations of physical and non-physical development, starting to open up to the outside community, but changes can occur without violating the Pikukuh set by Pu'un (the traditional head) The implementation of Baduy ethnicity policy includes the content of the policy and the policy environment which includes aspects of the affected interests, types of benefits, degrees of change and program implementers. The bottom-up approach is the most appropriate to be used in efforts to tackle the development of the Baduy community, where the community is positioned as an actor (subject) development which is expected to have a positive influence on the community empowerment process itself in an effort to build independence. Synchronization of various elements plays an important role in implementing Baduy development policies. With synchronization in the implementation process, the Baduy development policy will be implemented better.
\end{abstract}

Keywords: Policy Implementation, Baduy Tribe Development. 


\section{A. PENDAHULUAN}

Undang-undang nomor 23 Tahun 2014 tentang pemerintahan daerah, dengan prinsip otonomi yang luas, nyata dan bertanggung jawab, pelimpahan kewenangan dari pemerintah pusat kepada pemerintah daerah, percepatan masyarakat sejahtera dapat segera terwujud. Hal ini seperti ditegaskan dalam penjelasan umum Undang-undang nomor 23 Tahun 2014, yang berbunyi: Pemberian otonomi luas kepada daerah diarahkan untuk mempercepat terwujudnya kesejahteraan masyarakat melalui peningkatan pelayanan, pemberdayaan, dan peran serta masyarakat, serta daya saing dengan memperhatikan prinsip demokrasi, pemerataan, keadilan, keistimewaan dan kekhasan suatu daerah dalam system Negara Kesatuan Republik Indonesia (Haris, 2005; Seymour \& Turner, 2002).

Pasca reformasi, harapan publik tertumpu pada demokratisasi sebagai obat penawar untuk menyembuhkan penyakit- penyakit kronis dalam kehidupan berbangsa dan bernegara. Demokratisasi yang berlangsung hampir di seluruh belahan dunia membawa perubahan dalam berbagai aspek kehidupan ketatanegaraan, baik sistem, lingkungan maupun actor pelaksana kebijakan (Haris, 2005; Thoha, 2002). Semangat Desentralisasi dan otonomi daerah menggunakan otonomi yang dimiliki, mendorong daerah untuk berkreasi dan berinovasi dalam mengelola sumber daya yang tersedia secara optimal, termasuk pengelolaan sumberdaya manusia (Harmantyo, 2002).

Demikian pula desentralisasi kebijakan dalam pelayanan public merupakan langkah penting untuk mewujudkan tata pemerintahan yang baik (good governance). Beberapa kelemahan dari struktur pemerintahan yang sentralistik telah dipahami secara meluas dan mendorong Indonesia untuk menetapkan strategi desentralisasi dalam pelayanan public (Green, 2005). Tujuannya agar implementasi kebijakan desentralisasi mampu menciptakan sistem pemerintahan yang lebih efektif dan terciptanya partisipasi serta kreativitas masyarakat dalam pelaksanaan pelayanan public. Desentralisasi menghendaki agar pemerintah semakin didekatkan kepada masyarakat,sehingga pelayanan yang diberikan menjadi semakin baik (Batterbury \& Fernando, 2006).

Perubahan paradigma desentralisasi apabila dicermati lebih jauh dapat dipahami sebagai azas penyelenggaraan pemerintahan yang dipertentangkan dengan sentralisasi. Kebijakan desentralisasi menghasilkan pemerintahan lokal (local government) yang diarahkan kepada upaya meminimalisasi kelemahan penyelenggaraan pemerintahan yang sangat sentralistis (Jati, 2016). Desentralisasi merupakan pengalihan kewenangan dan sumber daya, dari pusat ke daerah. Karena pemerintahan pada hakekatnya bersangkut paut dengan 
pengelolaan otoritas Publik (performing public authority) dan sekaligus mewujudkan azas demokrasi dalam kehidupan berbangsa dan bemegara (Muluk, 2006).

Untuk mewujudkan hal tersebut di atas, diperlukan pemerintahan yang baik (Good Governance). Hal tersebut merupakan isu yang paling mengemuka yang dilakukan oleh masyarakat dewasa ini. Untuk itu, aparatur hendaknya dapat mengimbangi tuntutan masyarakat dengan memantapkan kepribadian yang berorientasi pada pelayanan dan pemberdayaan masyarakat, aparatur yang professional, memiliki kualitas dan integritas kepribadian yang mengacu pada moralitas yang luhur. Aparatur yang professional berarti tingkat keahlian dan keterampilannya cukup memadai, memiliki etos kerja dan disiplin kerja yang tinggi, sehingga pada akhirnya bermuara pada peningkatan kinerja dan produktivitas kerja yang optimal dan mampu memenuhi harapan masyarakat(Widodo, 2001)

Untuk melihat sejauh mana keberhasilan pembangunan dan kesejahteraan manusia, UNDP telah menerbitkan suatu indikator yaitu Indeks Pembangunan Manusia (IPM) untuk mengukur kesuksesan pembangunan dan kesejahteraan suatu negara. IPM adalah suatu tolak ukur angka kesejahteraan suatu daerah atau negara yang dilihat berdasarkan tiga dimensi yaitu: angka harapan hidup pada waktu lahir (life expectancy at birth), angka melek huruf (literacy rate) dan rata-rata lama sekolah (mean years of schooling), dan kemampuan daya beli (purchasing power parity). Indikator angka harapan hidup mengukur kesehatan, indikator angka melek huruf penduduk dewasa dan rata-rata lama sekolah mengukur pendidikan dan terakhir indikator daya beli mengukur standar hidup. Ketiga indikator tersebut saling mempengaruhi satu sama lain, selain itu dapat dipengaruhi oleh faktor-faktor lain seperti ketersediaan kesempatan kerja yang ditentukan oleh pertumbuhan ekonomi, infrastruktur, dan kebijakan pemerintah sehingga IPM akan meningkat apabila ketiga unsur tersebut dapat ditingkatkan dan nilai IPM yang tinggi menandakan keberhasilan pembangunan ekonomi suatu negara (UNDP, 1993).

Pembangunan manusia di Indonesia terus mengalami kemajuan. Pada tahun 2017, Indeks Pembangunan Manusia (IPM) Indonesia mencapai 70,81. Angka ini meningkat sebesar 0,63 poin atau tumbuh sebesar 0,90 persen dibandingkan tahun 2016. Bayi yang lahir pada tahun 2017 memiliki harapan untuk dapat hidup hingga 71,06 tahun, lebih lama 0,16 tahun dibandingkan dengan mereka yang lahir tahun sebelumnya. Anak-anak yang pada tahun 2017 berusia 7 tahun memiliki harapan dapat menikmati pendidikan selama 12,85 tahun (Diploma I), lebih lama 0,13 tahun dibandingkan dengan yang berumur sama pada tahun 2016. 
Situasi perekonomian negara ini yang setiap tahunnya mengalami perubahan semakin membaik secara langsung berdampak pada Indek Pembangunan Manusia di Indonesia, hal itupun terjadi di delapan kabupaten/Kota yang ada di Provinsi Banten. Pencapaian pembangunan manusia di kabupaten/kota pada tahun 2017 terlihat cukup bervariasi, dengan IPM tertinggi menjadi milik Kota Tangerang Selatan $(80,84)$ dan terendah untuk Kabupaten Lebak $(62,95)$. Kota Tangerang Selatan juga menjadi pemilik nilai tertinggi untuk setiap dimensi/komponen pembentuk IPM, sedangkan nilai terendah diduduki secara bergantian oleh Kabupaten Lebak dan Kabupaten Pandeglang (Arsita, 2018).

Baduy adalah salah satu nama suku bangsa diantara sejumlah suku bangsa yang terdapat di Indonesia. Kelompok masyarakat yang dikenal tertutup ini bermukim di pegunungan kendeng yang secara administratif merupakan bagian wilayah Desa Kanekes, Kecamatan Leuwidamar, Kabupaten Lebak, Provinsi Banten. Sesuai laporan registrasi penduduk Kabupaten Lebak Kecamatan Leuwidamar Desa Kanekes Tahun 2018 suku baduy berjumlah 11710 Orang, meliputi penduduk laki-laki 5890 Orang, dan penduduk perempuan 5820 Orang. Bila kita cermati dari data tersebut bahwa perkembangan jumlah suku baduy luar lebih banyak timbang baduy dalam karena baduy dalam hanya mendiami tiga kampung, yaitu kampung cibeo, kampung cikeusik dan kampung cikertawana, serta setiap kampung jumlah rumah (suhunan) tidak boleh lebih dari empat puluh rumah (suhunan). Sedangkan untuk suku baduy luar mendiami tiga puluh lima kampung dan jumlah rumah (suhunan) tidak dibatasi dengan sendirinya polulasi baduy luar menujukan jumlahnya sangat banyak dan cepat bertambah (Ahidin dkk, 2018).

Suku Baduy bukan merupakan suku terasing, melainkan suku yang sengaja mengasingkan diri (menutup diri) dengan maksud menjalankan Amanat Buyut atau pikukuh yaitu amanat yang digariskan para leluhur. Warisan leluhur yang telah tertanam kuat itu adalah pola hidup sederhana, menjauhi pengaruh-pengaruh budaya modern, merepresentasikan diri pada cara hidup yang dulu dilakukan oleh para leluhur tanpa merubahnya (Suparmini dkk, 2013).

Konsekwensi sebagai suku yang menutup diri, mengharuskan mereka memiliki kemampuan dalam menyediakan seluruh kebutuhan hidup, baik sandang, pangan maupun papan dari potensi sumber daya alam yang mereka miliki. Selain itu, mereka membangun sistem sosial budaya yang mengatur kehidupan dalam kelompok, mencakup aturan-aturan yang berisikan kewajiban-kewajiban, tindakan-tindakan yang diterima dan ditolak, tindakantindakan yang dilarang, tindakan-tindakan yang diizinkan serta sangsi-sangsi tertentu yang mengikat pada setiap tindakan yang menyimpang (Mustomi, 2017). 
Dalam penelitian ini hanya dibatasi implementasi kebijakan pembangunan suku baduy. Perubahan dan perkembangan social budaya dalam pembangunan masyarakat baduy demi kemajuan anggota masyarakat yang bersangkutan, menemukan penyesuaian diri bagi anggota masyarakat akan tetapi penyesuaian saja tidak cukup, menguasai keadaan baru lebih penting untuk menghindari kekacauan dalam masyarakat sebagai akibat dari perubahan tersebut. Seiring dengan kemajuan zaman tradisi dan kebudayaan daerah yang pada awalnya dipegah teguh, dipelihara dan dijaga keberadaannya oleh setiap suku,kini sudah hampir punah. Pada umumnya masyarakat merasa gengsi dan malu apabila masih mempertahankan dan menggunakan budaya lokal atau budaya daerah.

\section{B. METODE}

Penelitian ini menggunakan metode kualitatif. Penelitian kualitatif adalah penelitian yang bertolak dari pandangan bahwa fokus penelitian adalah kualitas hakekat dan esensi. McMillan \& Schumacher dalam Syamsuddin menyatakan bahwa penelitian kualitatif adalah suatu pendekatan yang juga disebut pendekatan investigasi karena biasanya peneliti mengumpulkan langsung dan berinteraksi dengan orang-orang di tempat penelitian. Dengan pendekatan kualitatif ini peneliti akan menggambarkan dan menganalisis setiap individu dalam kehidupan dan pemikirannya. Para peneliti yang menggunakan pendekatan ini harus mampu menginterpretasikan segala fenomena dan tujuan melalui sebuah penjelasan (Syamsuddin \& Vismaia, 2009).

Dilihat dari penelitian ini yang tepat menggunakan pendekatan kualitatif dengan alasan karena masalah penelitian yang dikaji memerlukan pengkajian secara terus menerus dan penelitian ini memerlukan pengkajian secara komprehensif, utuh, total, mendalam, terfokus dan mendalam. Penelitian kualitatif menurut Sukmadinata bahwa : penelitian kualitatif ditujukan untuk memahami fenomena-fenomena sosial dari sudut atau perspektif partisipan. Partisipan adalah orang-orang yang diajak wawancara, diobservasi, diminta memberikan data (Sukmadinata, 2011).

\section{HASIL DAN PEMBAHASAN}

\section{Kebijakan Pemerintah Daerah dalam Perlindungan Masyarakat Adat}

Kebijakan pemerintah merupakan kebijakan publik, yang merupakan sejumlah aktivitas pemerintah untuk memecahkan masalah di masyarakat, baik secara langsung maupun melalui lembaga yang mempengaruhi kehidupan masyarakat. Pengaruh dari tindakan atau aktivitas pemerintah tersebut ialah: adanya pilihan kebijakan yang dibuat, output 
kebijakan, dan dampak kebijakan yang mempengaruhi kehidupan masyarakat (Tangkilisan, 2003).

Kebijakan pemerintah daerah yang diharapkan oleh masyarakat adat adalah dalam perlindungan hak-hak masyarakat adat. Hak-hak Masyarakat Kasepuhan yang harus diakui, dihormati, dilindungi, dan dipenuhi oleh Pemerintah Daerah menurut Perda Kabupaten Lebak No 8 Tahun 2017 adalah: 1) hak ulayat; 2) hak perorangan warga Kasepuhan atas tanah dan sumber daya alam; 3) hak memperoleh pembagian manfaat dari sumber daya genetik dan pengetahuan tradisional oleh pihak luar; 4) hak atas pembangunan; 5) hak atas spiritualitas dan kebudayaan; 6) hak atas lingkungan hidup; 7) hak untuk mendapatkan layanan pendidikan khusus; 8) hak untuk mendapatkan layanan kesehatan; 9) hak untuk mendapatkan layanan administrasi kependudukan; 10) hak untuk mengurus diri sendiri; 11) hak untuk menjalankan hukum dan peradilan adat; 12) hak untuk didengar aspirasinya dalam penyelenggaran pemerintahan desa dan pemilihan kepala desa; dan 13) hak-hak lain yang diatur dalam peraturan perundang-undangan. Hak atas tanah dan sumber daya alam merupakan salah satu hak paling penting bagi masyarakat adat sebab keberadaan hak tersebut menjadi salah satu ukuran keberadaan suatu komunitas masyarakat adat (Arizona, 2010).

Nababan (2009), menyebutkan dari sekian banyak kategori hak yang berhubungan dengan masyarakat adat, setidaknya ada empat hak masyarakat adat yang paling sering disuarakan, antara lain: 1) Hak untuk "menguasai"(memiliki,mengendalikan) dan mengelola (menjaga, memanfaatkan) tanah dan sumber daya alam di wilayah adatnya; 2) Hak untuk mengatur diri sendiri sesuai dengan hukum adat (termasuk peradilan adat) dan aturan-aturan adat yang disepakati bersama oleh masyarakat adat;3) Hak untuk mengurus diri sendiri berdasarkan sistem kepengurusan/kelembagaan adat; dan 4) Hak atas identitas, budaya, sistem kepercayaan ('agama'), sistim pengetahuan (kearifan tradisional) dan bahasa asli. Demikian pula pada tataran nasional hak-hak masyarakat adat juga sudah diatur oleh undangundang seperti yang ditunjukkan oleh UU Pemerintahan Daerah, UU HAM, UU Kehutanan, UU Sumber Daya Air, UU Perkebunan, UU Pengelolaan Wilayah Pesisir dan Pulau-pulau Kecil, dan UU Perlindungan dan Pengelolaan Lingkungan Hidup. Di tingkat Provinsi Banten belum ada aturan-aturan khusus mengenai masyarakat adat. Namun demikian setidaknya ada Rancangan Peraturan Daerah Provinsi Banten mengenai Budaya Daerah 2017 yang mengarah pada perlindungan masyarakat adat.

Berdasarkan gambaran dua pasal Raperda di atas, dapat diketahui bahwa Provinsi Banten belum memiliki aturan khusus mengenai perlindungan masyarakat adat. Lebak sebagai kabupaten di Provinsi Banten yang memiliki masyarakat adat Baduy dan Kasepuhan 
Banten Kidul. Kabupaten Lebak memiliki setidaknya memiliki dua Peraturan Daerah yaitu: 1) Perda Kabupaten Lebak No.32/2001 tentang Perlindungan atas Hak Ulayat Masyarakat Baduy dan 2) Perda Kabu-paten Lebak No. 8/2017 tentang Pengakuan, Perlindungan dan Pember-dayaan Masyarakat Hukum Adat Kasepuhan. Di tingkat Pemerintahan paling bawah, Desa Kanekes sudah memiliki Perdes No. 01/2007 tentang Saba Budaya dan Perlindungan Masyarakat Adat Tatar Kanekes (Baduy).

a. Perda Kabupaten Lebak No. 32/2001 tentang Perlindungan atas Hak Ulayat Masyarakat Baduy

Isi dari Perda Kabupaten Lebak No. 32/ 2001 mencakup: ketentuan umum; hak ulayat masyarakat baduy yang meliputi: penetapan hak ulayat dan pengecualian terhadap hak ulayat masyarakat baduy; batasbatas hak ulayat masyarakat baduy yang meliputi: batas desa dan batas alam, ketentuan pidana; ketentuan penyidikan; ketentuan lain-lain; dan ketentuan penutup. Perda ini lahir atas inisiatif masyarakat Baduy karena dilatarbelakangi oleh beberapa faktor yaitu: 1) banyaknya penebangan dan pembalakan liar di wilayah/lahan Baduy oleh masyarakat luar Baduy; 2) pencurian hasil tanaman masyarakat Baduy oleh orang luar; dan 3) pergeseran batas wilayah yang dilakukan oleh orang luar di daerah perbatasan Baduy, yaitu Sobang, Muncang,Bojongmanik, dengan alasan bahwa tanah yang digarap itu milik negara.

Berdasarkan hasil wawancara dengan Jaro Baduy, Edih Mulyadi (tanggal 20/12/2018) sebelum Perda ini muncul, terdapat 17 titik lahan yang digarap oleh masyarakat luar yang sebenarnya itu adalah wilayah Baduy. Karena alasan dan permasalahan tersebut, masyarakat Baduy berusaha mengatasi masalaah tersebut bersama tokoh masyarakat Baduy di Desa Kanekes, Dinas Kehutanan, dan Kementrian Lingkungan Hidup, sampai ke Presiden Abdurahman Wahid. Tahap awal yang dilakukan Jaro mendesak para tokoh adat agar segera bermusyawarah atas usulan pembuatan perda hak ulayat. Selanjutnya, Jaro Daenah bersama pejabat Desa, tokoh lembaga adat, melakukan koordinasi dengan Mentri Dalam Negeri (Yogi S. M.), Menteri Lingkungan Hidup (Erna Witular) hingga menghadap ke Presiden. Hasil koordinasi mendapatkan respon yang baik hingga Perda hak ulayat terwujud. Walaupun Perda sudah diundangkan namun implementasinya masih mengalami beberapa permasalahan diantaranya adalah:

1). Sosialisasi masih minim, sehingga masih ada kasus penebangan, pembalakan liar, dan pencurian hasil hutan di wilayah perbatasan Baduy;

2). Adanya kasus rencana pengeboran minyak di wilayah Baduy 
b. Perda Kabupaten Lebak No. 8/2017 tentang Pengakuan, Perlindungan dan Pemberdayaan Masyarakat Hukum Adat Kasepuhan

Isi Perda Kabupaten Lebak No. 8/2017 terdiri dari: ketentuan umum; asas, tujuan, dan ruang lingkup; keberadaan dan kedudukan hukum kasepuhan; wilayah adat; hak masyarakat hukum adat kasepuhan; lembaga adat; hukum adat; pemberdayaan masyarakat hukum adat kasepuhan; penyelesaian sengketa; ketentuan penutup. Berdasarkan hasil wawancara dengan informan kunci, pada umumnya masyarakat di Citorek sudah mengetahui perda No.8/ 2017 tentang Pengakuan, Perlindungan dan Pemberdayaan Masyarakat Hukum Adat Kasepuhan karena perda ini lahir dari tuntutan masyarakat Citorek dan masyarakat adat lainnya yang menginginkan hak-hak masyarakat adat terlindungi oleh negara. Sebelum lahirnya Perda tersebut, Citorek hanya sebatas desa pada umumnya berbasis masyarakat adat. Dengan adanya Perda Masyarakat Adat, eksistensi masyarakat adat akan terjaga karena masyarakat adat berbeda dengan masyarakat desa pada umumnya.

Salah satu perbedaan sistem pemerintahan masyarakat adat dengan sistem pemerintahan desa pada umumnya adalah dalam proses pemilihan Kepala Desa di mana masyarakat adat tidak mengikuti aturan pemilihan yang sudah ditetapkan pemerintah, tetapi berdasarkan sistem yang dibuat oleh masyarakat adat itu sendiri dan lembaga adat dikontrol oleh lembaga adat. Salah satu faktor yang mendorong lahirnya Lahirnya Perda No.8/2017 adalah tumpang tindihnya pengeleloaan lahan antara masyarakat Citorek dengan Taman Nasional Gunung Halimun Salak. Pada mulanya Taman Nasional Halimun Salak tidak mencakup masyarakat adat. Namun, setelah dikeluarkannya SK Kemenhut No. 175/KptsII/2003 tentang perluasan Taman Nasional Gunung Halimun Salak oleh pemerintah, luas Taman Nasional semakin melebar dan mencakup wilayah adat. Undang-Undang No.41/1999 tentang kehutanan menjelaskan bahwa "Hutan adat adalah Hutan Negara yang berada di Wilayah Masyarakat adat”. Atas dasar undang-undang ini pihak Taman Nasional lebih leluasa dalam mengelola lahan, bahkan bisa menuntut masyarakat ke ranah hukum. Undangundang tersebut menimbulkan konflik di masyarakat, sehinga masyarakat mengajukan banding ke Mahkamah Konstitusi. Akhirnya MK merevisi poin dalam undang-undang tersebut yang disebut MK 35, yang berbunyi: "Hutan Adat adalah Hutan yang berada di Wilayah Masyarakat Adat”. Meskipun MK sudah merevisi undangundang tersebut, namun Citorek sebagai masyarakat adat belum diakui secara legal oleh pemerintah, karena berdasarkan undang-undang No.41/1999, dalam point yang lain, disebutkan bahwa keberadaan masyarakat adat ditentukan oleh pemerintah daerah. Berdasrkan itulah 
masyarakat Citorek mendorong pemerintah agar segera membuat perda tentang masyarakat adat.

Berdasarkan hasil wawancara dari responden, beberapa harapan yang disampaikan msyarakat adalah berkaitan dengan infrastruktur, sistem pemerintahan khusus di masyarakat adat, perlindungan tanah masyarakat adat, dukungan pengembangan upacara adat, dan perlindungan eksistensi masyarakat adat. Masyarakat membutuhkan infrastruktur yang baik, terutama akses jalan. Diakuinya Citorek sebagai masyarakat adat, akan menjadi perhatian masyarakat dari luar. Akses yang mudah akan mendorong Citorek menjadi desa Wisata yang pada gilirannya dapat meningkatkan perekonomiannya masyarakat. Salah satu hak masyarakat yang juga harus dipenuhi adalah anggaran untuk Seren Taun dan pesta adat lainnya harus dianggarkan dari APBD. Masyarakat berharap jangan sampai ada kesan masyarakat mengemis kepada pemerintah meminta sumbangan untuk acara Seren Taun. Selain itu, pemerintah juga harus memberikan otonomi kepada masyarakat adat dalam pemilihan Kepala Desa tidak melalui pemilihan kepala desa dengan pencoblosan, tetapi melalui musyawarah menurut adat. Menurut masyarakat adat Desa Citorek, pemilihan melalui sistem pemilu hanya akan menimbulkan disharmoni antar masyarakat. Dalam tradisi masyarakat Citorek, bagaimanapun perpecahan adalah hal yang sangat dilarang, masyarakat Citorek menjunjung tinggi nilai-nilai persaudaraan. Berkaitan dengan masalah tanah adat, pemerintah juga harus membuat sertifikat khusus untuk hutan atau lahan yang dikelola masyarakat adat atas nama kasepuhan adat, bukan atas nama pribadi.

\section{Peran DPRD dalam Meningkatkan Pembangunan Masyarakat Baduy}

Peran DPRD harus mampu menjaring aspirasi masyarakat dalam upaya mendekatkan penerapan kebijakan sesuai dengan kebutuhan masyarakat. Aspirasi masyarakat adalah harapan dan tujuan dari masyarakat untuk keberhasilan pada masa yang akan datang berkaitan dengan hajat hidup mereka, baik secara individu maupun secara kelompok. Masyarakat harus dijadikan sebagai bahan pertimbangan dalam menyusun rencana dan kebijakan oleh pemerintah daerah dan DPRD, dan bukan hanya merupakan hasil dari interaksi pemerintah daerah dan DPRD. Dan juga diperlukan penguatan peran kelompok kepentingan dan pers di daerah untuk mendorong DPRD lebih aspiratif. Pasal 53 Undangundang No. 10 Tahun 2004 tentang pembentukkan peraturan perundang-undangan, telah menjamin hak masyarakat dalam memberikan masukan penyusunan kebijakan tanpa memerinci implikasinya bagi pemerintah, karena penjelasan UU ini menyatakan bahwa teknis penjaminan hak masyarakat ini diatur dalam Tata Tertib DPRD. Kendati ini membantu 
transparansi dan akuntabilitas pemerintah dalam implementasi kebijakan nantinya, ia tidak memadai untuk memastikan lahirnya kebijakan yang aspiratif.

Salah satu tuntutan pemekaran dalam upaya meningkatkan kesejahteraan masyarakat dilakukan melalui percepatan pertumbuhan kehidupan demokrasi didalam masyarakat. Menumbuhkan dan membangun kehidupan demokrasi dilakukan dengan membuka ruang partisipasi bagi masyarakat yang harus dapat diperankan oleh wakil rakyat yang ada di daerah yaitu DPRD. Peran DPRD dalam membangun partisipasi masyarakat perlu dilaksanakan, supaya kebijakan pembangunan yang ada di daerah berjalan sesuai dengan kebutuhan masyarakat yang ada di daerah. Oleh karena itu, untuk menilai peran DPRD dalam membangun partisipasi masyarakat atau penyerapan aspirasi masyarakat yang dilaksanakan oleh DPRD Kabupaten Lebak dapat diuraikan sebagai berikut:

a. Secara formal

Pengaduan dan/atau aspirasi masyarakat dapat ditindaklanjuti dengan rapat dengar pendapat umum, rapat dengar pendapat, kunjungan kerja atau rapat kerja alat kelengkapan DPRD dengan mitra kerjanya. Kemudian tata cara penerimaan dan tindak lanjut pengaduan dan/atau aspirasi masyarakat diatur oleh sekretaris DPRD dengan persetujuan pimpinan DPRD. Oleh karena dalam upaya melaksanakan perannya DPRD untuk membangun partisipasi masyarakat, dilakukan dengan cara :

1). Reses

Reses merupakan kegiatan yang diatur dalam perundang-undang untuk menyerap aspirasi masyarakat yang menjadi konstituennya pada daerah pemilihan anggota dewan masing-masing. Masa reses dilaksanakan paling lama 6 (enam) hari kerja dalam 1 (satu) kali reses. Masa reses dipergunakan oleh anggota DPRD secara perseorangan atau kelompok untuk mengunjungi daerah pemilihannya guna menyerap aspirasi masyarakat. Anggota DPRD secara perseorangan atau kelompok wajib membuat laporan tertulis atas hasil pelaksanaan tugasnya pada masa reses yang disampaikan kepada pimpinan DPRD dalam rapat paripurna. Kegiatan reses ini dilakukan oleh DPRD untuk menyerap aspirasi masyarakat baik secara perorangan maupun kelompok di daerah pemilihan masing-masing yang telah ditentukan.

2). Kunjungan kerja atau sidak

Kunjungan kerja atau sidak merupakan kegiatan penyerapan aspirasi masyarakat yang dilakukan untuk menyelesaikan permasalahan-permasalahan khusus yang dihadapi oleh masyarakat. Sehingga anggota dewan yang turun untuk melakukan sidak atau kunjungan kerja tidak harus anggota dewan yang berasal dari daerah pemilihannya. Bisa saja anggota 
dewan yang berasal dari daerah pemilihan yang berbeda, yang penting bertujuan untuk menampung aspirasi masyarakat guna menyelesaikan permasalahan khusus yang dihadapi.

b. Secara Informal

Implementasi peran DPRD dalam membangun partisipasi masyarakat tidak hanya dilakukan secara formal saja seperti yang sudah diatur dalam peraturan perundang-undangan. Tetapi juga dilakukan secara informal dalam upaya menggali partisipasi masyarakat dalam kegiatan yang dilakukan dalam pemerintahan daerah. Upaya-upaya yang dilakukan anggota dewan dalam menggali aspirasi dan partisipasi masyarakat melalui kegiatan secara informal style masing-masing.

Kegiatan informal yaitu blusukan yang dilakukan anggota dewan meliputi menghadiri acara kondangan, menghadiri acara pemakaman, menghadiri acara keagamaan, coffee morning, kegiatan di ranting partai di kecamatan dan acara dewan pulang kampung. Semua kegiatan informal melalui blusukan dilakukan oleh anggota dewan dalam rangka menampung semua aspirasi yang disampaikan oleh masyarakat. Bahkan dengan begitu terbukanya anggota dewan dalam kegiatan blusukan yang dilakukan kepada masyarakat, membuat masyarakat tidak ada rasa ragu untuk menyampaikan seluruh keluhannya. Keluhan-keluhan masyarakat semuanya akan disampaikan kepada setiap anggota dewan yang melakukan blusukkan, baik keluhan yang bersifat kelompok ataupun pribadi. Realitas ini terkadang membuat para anggota dewan kewalahan menampung setiap keluhan yang disampaikan oleh masyarakat. Apalagi masyarakat yang masih berfikir pragmatis bahwa setiap keluhan yang disampaikan kepada anggota dewan pasti akan ditanggapi dan diwujudkan, membuat setiap masyarakat yang bertemu langsung dengan anggota dewan memiliki harapan untuk dapat menyelesaikan masalahnya. Misalnya seperti keluhan tentang keluarga yang sedang sakit dan membutuhkan pembiayaan untuk perawatannya, tidak jarang anggota dewan harus mengeluarkan anggaran pribadinya untuk membantu masyarakat yang menyampaikan keluhan tersebut. Bantuan yang diberikan anggota dewan terkadang juga tidak dapat membantu sepenuhnya, namun cukup untuk memberikan spirit kepada masyarakat bahwa wakil mereka memiliki perhatian terhadap permasalahan yang dihadapi oleh masyarakat. Fakta inilah yang membuat anggota dewan terkadang juga jarang melakukan blusukkan ke seluruh wilayah pemilihannya, disebabkan aspirasi yag disampaikan oleh masyarakat memiliki harapan yang tinggi untuk direalisasikan. 


\section{Manfaat Kebijakan Pembangunan Masyarakat Baduy}

Kebijakan pembangunan masyarakat baduy baik fisik maupun non fisik seharusnya memberikan manfaat bagi masyarakat baduy. Manfaat yang dirasakan akan membuahkan dukungan terhadap kebijakan pemerintah. Selama ini perhatian pemerintah terhadap pembangunan masyarakat baduy dirasakan sangat terbatas, sehingga seringkali memicu kekecewaan masyarakat terhadap pemerintah.

Kehidupan suku Baduy memiliki ketergantungan besar terhadap alam. Ketergantungan ini diimbangi dengan menjaga alam dari kerusakan. Peneliti Biologi UNPAD, Johan Iskandar dalam Depsos (2006) melaporkan, dari batas paling luar Baduy hingga kawasan hutan sakral di selatan Kampung Cikeusik, Baduy Dalam, tercatat tidak kurang dari 36 anak sungai mengalir ke Sungai Ciujung. Keberadaan hutan, tanah, dan air di kawasan Baduy telah menjadi satu kesatuan ekosistem yang terintegrasi, membentuk hubungan timbal balik saling mempengaruhi dengan sistem sosial. Berdasarkan pola pengelolaan tata ruangnya, kawasan Baduy secara umum dibedakan menjadi tiga, yaitu zona permukiman, zona pertanian ladang dan hutan sekunder bekas ladang, serta zona hutan perlindungan /hutan titipan.

Praktiknya, hak-hak masyarakat adat acapkali diabaikan dalam kasus eksploitasi sumber daya alam di wilayah-wilayah komunitas adat. Kedudukan komunitas adat cenderung lemah, karena belum ada regulasi bersifat khusus yang mengakui dan melindungi hak-hak masyarakat adat. Di Baduy, kedudukan masyarakat adatnya amatlah kuat. Sebab, hak-hak masyarakat adat Baduy dilindungi oleh regulasi khusus yang dituangkan dalam Peraturan Daerah (Perda) pada era otonomi daerah ini. Desa Kenekes ditetapkan sebagai tanah hak ulayat, seperti yang tertuang dalam Peraturan Daerah (Perda) Kabupaten Lebak Nomor 32 Tahun 2001 tentang Perlindungan atas Hak Ulayat Masyarakat Baduy dijabarkan kembali dengan Peraturan Desa (Perdes) Desa Kanekes No 1 Tahun 2007. Dengan tanah hak ulayat seluas 5.130,36 ha, masyarakat Baduy mendapat kewenangan untuk mengelola sendiri kawasan adat tersebut. Dan, inilah satu-satunya masyarakat adat di Indonesia yang sudah memiliki regulasi yang mengakui hak-hak masyarakat adat. Kiranya, kearifan lokal Baduy ini bisa menjadi cermin bagi wilayah-wilayah lainnya pada masa otonomi daerah saat ini.

Dalam pengolahan sumber daya alam, para pengambil kebijakan negeri ini perlu belajar dari orang-orang Baduy. Suku Baduy sudah membuktikannya, bahwa pengelolaan alam khususnya hutan di kawasan bumi Baduy telah membuat hidup mereka bisa survive. Kesadaran masyarakat Baduy terhadap lingkungan hidup, khususnya dalam menjaga kelestarian hutan dan air sungguh luar biasa. Ada pikukuh masyarakat adat Baduy yang 
sampai kini masih dipegang teguh, "gunung ulah dilebur, lebak ulah dirusak" artinya gunung jangan dihancurkan, sawah jangan dirusak.

Selama ini, komunitas masyarakat adat Baduy hanya dilindungi dengan Peraturan Daerah (Perda) Kabupaten Lebak Nomor 32 Tahun 2001 tentang Perlindungan atas Hak Ulayat Masyarakat Baduy. Tanah ulayat seluas 5.136,38 hektare dihuni sekitar 11.800 jiwa penduduk. Perda tersebut dipertegas Keputusan Bupati Lebak Nomor 590/Kep.233/Huk/2002 tentang Penetapan Batas-batas Detail Tanah Ulayat Masyarakat Adat Baduy di Desa Kanekes.

Masyarakat Baduy bersikap kooperatif. Atas dasar keteguhan terhadap adat tradisi yang mereka yakini, mereka melakukan "sowan" baik pemerintahan daerah maupun pusat. Bahkan, menyebut presiden "Bapak Gede" suatu bentuk penghormatan. Cara mereka menuntut hak-hak, sama sekali tidak menggunakan cara arogan, dengan demontrasi, misalnya, sebagaimana banyak dilakukan masyarakat terdidik dan menaku modern. Ataupun seperti dilakukan kelompok separatis tertentu. Sungguh, mereka benar-benar menjunjung tinggi etika, menjalani suatu sikap terpuji yang dalam masyarakat modern sudah langka. Dari sikap masyarakat Baduy yang demikian itu, selayaknya pemerintah beserta seluruh masyarakat mengapresiasi. Sudah sepatutnya mereka mendapatkan yang mereka dambakan. Mereka bukan mengharapkan penghargaan Kalpataru atau bantuan materi sebagaimana diharapkan masyarakat kebanyakan.

Satu hal yang mereka dambakan, legalitas hukum sebagai bentuk perlindungan demi eksistensi mereka beserta adat tradisi yang menjunjung tinggi kelestarian dan keseimbangan lingkungan alam maupun sosial. Dengan mangharap diberikannya legalitas hukum sekaligus menegaskan, bahwa mereka tetap setia sebagai bagian dari Negara Kesatuan Republik Indonesia (NKRI). Maka, sangat ironis apabila aspirasi mereka oleh pemerintah tidak ditanggapi secara positif.

Tanpa undang-undang yang mengatur tata kehidupan mereka, sebenarnya telah ada aturan adat, bahkan berlaku cukup adil, diimplementasikan secara efektif dan kontinyu, secara turun-temurun. Pelaksanaan aturan adat Baduy dipimpin oleh seorang kepala adat yang disebut puun. Mereka memdambakan legalitas hukum justru guna melindungi eksistensi mereka dari 'gempuran' pihak-pihak dari luar komunitas mereka akibat pesatnya perkembangan jaman yang dipengaruhi faktor ekonomi, politis, dan budaya modern yang cenderung eksploitatif dan tanpa etika.

Kesetiaan masyarakat Baduy kepada pemerintah juga tercermin dalam adat tradisi yang disebut seba. Seba adalah kegiatan rutin masyarakat adat Baduy dan merupakan tradisi 
yang diwariskan secara turun-temurun untuk menghadap pemerintah (Ratu dan Menak) secara resmi dengan tujuan utama menjalin, mempererat silaturahmi, melaporkan situasi dan kondisi Baduy secara khusus dan lingkungan lain secara umum serta menyampaikan aspirasi dan harapan sehingga terjalin kerja sama untuk saling mendo'akan dan saling melindungi (Kurnia dkk, 2010).

Kentalnya tradisi tutur atau bahasa lisan pada masyarakat Baduy, membuat aturan adat tertuang dalam bentuk pepatah yang disampaikan dari mulut ke mulut. Aturan dan etika misalkan berupa larangan dengan ciri kata teu beunang (tidak boleh) atau ulah (jangan); keharusan dengan ciri kata kudu(harus); sebab-akibat dengan kata mun (kalau) dan mantak (maka). Contohnya, gunung teu beunang dilebur(gunung tidak boleh dirusak); ulah cuweut kanu hideung (jangan meledek pada yang hitam); kudu teguh kudu patuh (harus teguh harus taat).

\section{KESIMPULAN}

Keberadaan hak tanah ulayat (adat) suku Baduy sudah diatur melalui Perda No 35/2001 tentang perlindungan atas hak ulayat masyarakat Baduy yang dikeluarkan Pemkab Lebak. Implementasi kebijakan tersebut mempengaruhi kondisi masyarakat di Baduy tersebut selama ini terisolir dan tertinggal karena keterbatasan pembangunan fisik maupun non fisik mulai terbuka dengan masyarakat luar, orang Baduy dalam merupakan yang paling patuh kepada seluruh ketentuan maupun aturan-aturan yang telah ditetapkan oleh Pu'un (Kepala Adat). Akan tetapi seiring berjalannya waktu banyak wisatawan baik dalam maupun luar negeri yang datang mengunjungi suku Badui dengan membawa pengaruh yang bermacam-macam yang jelas berbeda dengan adat Baduy. Walaupun demikian perubahan dapat terjadi tanpa melanggar pikukuh, karena memang perbuatan tersebut dikehendaki atau keadaan yang memaksa sehingga perubahan terjadi diluar kehendak mereka, sehingga muncul toleransi dari pemuka adat terhadap hal itu.

Kebijakan pembangunan masyarakat baduy baik fisik maupun non fisik seharusnya memberikan manfaat bagi masyarakat baduy. Manfaat yang dirasakan akan membuahkan dukungan terhadap kebijakan pemerintah. Selama ini perhatian pemerintah terhadap pembangunan masyarakat baduy dirasakan sangat terbatas, sehingga seringkali memicu kekecewaan masyarakat terhadap pemerintah. Hak-hak masyarakat adat acapkali diabaikan dalam kasus eksploitasi sumber daya alam di wilayah-wilayah komunitas adat. Kedudukan komunitas adat cenderung lemah, karena belum ada regulasi bersifat khusus yang mengakui dan melindungi hak-hak masyarakat adat. Dengan adanya Peraturan Daerah (Perda) 
Kabupaten Lebak Nomor 32 Tahun 2001 tentang Perlindungan atas Hak Ulayat Masyarakat Baduy dijabarkan kembali dengan Peraturan Desa (Perdes) Desa Kanekes No 1 Tahun 2007 setidaknya keberadaan tanah hak ulayat seluas 5.130,36 ha, masyarakat Baduy mendapat kewenangan untuk mengelola sendiri kawasan adat tersebut. Dan, inilah satu-satunya masyarakat adat di Indonesia yang sudah memiliki regulasi yang mengakui hak-hak masyarakat adat. Kiranya, kearifan lokal Baduy ini bisa menjadi cermin bagi wilayahwilayah lainnya pada masa otonomi daerah saat ini.

Konsistensi masyarakat Baduy akan adat tradisi mereka berimplikasi terlestarikannya budaya Nusantara. Adat tradisi masyarakat Baduy yang memiliki keunikan bagian dari kekayaan budaya Nusantara. Keteguhan masyarakat Baduy mepertahankan adat warisan leluhur mereka merupakan bentuk konkret dalam mempertahankan keanekaragaman budaya. Konsistensi itulah telah terbukti berabad-abad yang kini sudah langka. Keteguhan masyarakat Baduy hidup dengan adat yang mereka yakini, oleh sebagian besar masyarakat, bahkan pemerintah kadang dipandang sebelah mata. Mereka dianggap tertinggal, tak berpartisipasi demi kemajuan bangsa. Stigma demikian, sebagai bentuk sikap yang merendahkan mereka. Bagi pemerintah, merupakan tudingan bahwa mereka menghambat kemajuan bangsa.

\section{DAFTAR PUSTAKA}

Ahidin, U., Handayani, R., \& Suraya, A. (2018). Penyuluhan Manajemen Informasi Dengan Mempertahankan Kehidupan Sosial Budaya Masyarakat Suku Baduy. Jurnal Pengabdian Dharma Laksana, 1(1), 1-10.

Arizona, Y. (2010). Satu Dekade Legislasi Masyarakat Adat: Trend Legislasi Nasional tentang Keberadaan dan Hak-hak Masyarakat Adat atas Sumber Daya Alam di Indonesia (1999-2009). Jakarta: Yance Arizona.

Arsita, A. (2019). Analisis Pengaruh Pertumbuhan Ekonomi, Ipm, Aglomerasi, Dan Belanja Pemerintah Daerah Terhadap Ketimpangan Pembangunan Antar Wilayah Kabupaten/Kota Di Provinsi Banten Tahun 2013-2017 (Bachelor's thesis, Fakultas Ekonomi dan Bisnis UIN Jakarta).

Batterbury, S. P., \& Fernando, J. L. (2006). Rescaling governance and the impacts of political and environmental decentralization: An introduction. World Development, 34(11), 1851-1863.

Green, K. (2005). Decentralization and good governance: The case of Indonesia. Available at SSRN 1493345.

Haris, S. (2005). Desentralisasi dan Otonomi Daerah: Desentralisasi, Demokratisasi \& Akuntabilitas Pemerintahan Daerah. Jakarta: Yayasan Obor Indonesia.

Harmantyo, D. (2007). Pemekaran Daerah dan Konflik keruangan Kebijakan otonomi daerah dan Implementasinya di Indonesia. MAKARA:Journal of Science, 11(1), 16-22. 
Jati, W. R. (2016). Inkonsistensi paradigma otonomi daerah di Indonesia: Dilema sentralisasi atau desentralisasi. Jurnal Konstitusi, 9(4), 743-770.

Kurnia, A., Sihabudin, A., \& Yustianti, F. (2010). Saatnya Baduy bicara: lojor teu meunang dipotong, pondok teu meunang disambung, gunung teu meunang dilebur, lebak teu meunang dirusak, buyut teu meunang dirobah. Jakarta: Bumi Aksara.

Muluk, M. R. K. (2006). Desentralisasi dan pemerintahan daerah. Yogyakarta: Banyumedia.

Mustomi, O. (2017). Perubahan Tatanan Budaya Hukum pada Masyarakat Adat Suku Baduy Provinsi Banten. Jurnal Penelitian Hukum De Jure, 17(3), 309-328.

Nababan, A. (2009). Mengidentifikasi Masyarakat Adat di Indonesia: Pandangan dan Pengalaman AMAN. Makalah dipresentasikan dalam Konsultasi CSO-KLH,16 Oktober, 2009.

Seymour, R., \& Turner, S. (2002). Otonomi daerah: Indonesia's Decentralisation Experiment. New Zealand Journal of Asian Studies, 4, 33-51.

Sukmadinata, N. S. (2011). Metode Penelitian dan Pendidikan. Bandung: Remaja Rosdakarya.

Suparmini, S., Setyawati, S., \& Sumunar, D. R. S. (2013). Pelestarian Lingkungan Masyarakat Baduy Berbasis Kearifan Lokal. Jurnal Penelitian Humaniora, 18(1).

Syamsuddin, A. R., \& Vismaia S. D. (2009). Metode Penelitian Pendidikan Bahasa. Bandung: Remaja Rosdakarya.

Tangkilisan, H. N. (2003). Implementasi Kebijakan Publik. Yogyakarta: Lukman Offset YPAPI.

Thoha, M. (2007). Birokrasi pemerintah Indonesia di era reformasi. Jakarta: Kencana.

United Nations Development Programme. (1993). Human Development Report 1993. New York: Oxford University Press.

Widodo, J. (2001). Good governance: telaah dari dimensi akuntabilitas dan kontrol birokrasi pada era desentralisasi dan otonomi daerah. Jakarta: Insan Cendekia. 